\title{
Do parents' flexible working hours affect fathers' contribution to domestic work? Evidence from a factorial survey
}

\author{
Gerhard Krug \\ Institute for Employment Research (IAB), Nuremberg, Germany; gerhard.krug@iab.de \\ University of Erlangen-Nuremberg (FAU), Germany; gerhard.krug@fau.de \\ Sebastian Bähr \\ Institute for Employment Research (IAB), Nuremberg, Germany; sebastian.baehr@iab.de \\ Katharina Diener \\ Institute for Employment Research (IAB), Nuremberg, Germany; katharina.diener@iab.de \\ Martin Abraham \\ University of Erlangen-Nuremberg (FAU), Germany; martin.abraham@fau.de
}

\begin{abstract}
This paper investigates the impact of fathers' flexible working hours on their willingness to contribute to domestic work. We first hypothesize that fathers will contribute more if they have the possibility to work flexible hours. Second, fathers are assumed to contribute less if their female partners have the possibility to work flexible hours. We test our hypotheses using data from a vignette study, where fathers evaluate hypothetical job offers to their non-employed partner with regard to the contribution to domestic work they are willing to offer if their partner accepts the job. We find that fathers' flexible hours increase their willingness to contribute to childcare but not to household work, partially supporting hypothesis one. Regarding hypothesis two, we find no effects of the female partner's flexible working hours on fathers' contribution to childcare or household work. We conclude our paper with some policy implications.
\end{abstract}

\section{Keywords}

Flexible working hours, schedule control, flextime, domestic work, childcare, household work

Acknowledgements: Previous versions of this paper have been presented at the 2015 conference "The science of choice. How to model the decision-making process?"of the Max Planck Institute for Demographic Research and the 2015 autumn conference of the "Sektion Familiensoziologie der DGS" at the University of Heidelberg. We thank the participants for their input. 


\section{Introduction}

Despite the sharp rise in female employment during the past decades (Blossfeld, 1997; Rosenfeld and Birkelund, 1995), empirical research shows that the division of family work is still highly gender-segregated, with women doing most of the domestic work (Bianchi et al., 2000; Presser, 1994; Sayer, 2005). This is especially pronounced for families with children since a shift in couples' division of labor towards more gender-specific arrangements occurs with the transition to parenthood (Schulz, 2010; Dechant, Rost and Schulz, 2014; Grunow, Schulz and Blossfeld, 2012; Schober, 2011; Dechant and Blossfeld, 2015). As a consequence, a high proportion of mothers work only part-time or drop out of the labor force for a restricted period to reconcile work and household demands (Rosenfeld, Trappe and Gornick, 2004; Kühhirt, 2012).

Against this background, there has been an increasing effort to identify factors that support the labor force integration of mothers. Here, specifically, the organization of work has come into focus. It is assumed that more flexible employment conditions can help mothers combine family and career. This comprises, e.g., more and higher qualified part-time jobs (Hill et al., 2004), shorter periods of maternal employment interruptions (Frodermann, Müller and Abraham, 2013; Drasch, 2013; Schober, 2013; Evertsson, Grunow and Aisenbrey, 2016), or higher flexibility of working hours. In particular, flexible working hours, that is, work arrangements where the duration of working time is fixed, but the position or distribution of the hours varies over the day or the working week (Nijp et al., 2016, should allow parents to better synchronize their working time with their children's school or kindergarten schedule as well as their partner's work schedule (Bryan and Sevilla, 2017; Hallberg, 2003; Wheatley, 2017).

However, although more flexible working conditions help reconcile household, childcare, and employment, their effects on the division of domestic work are often neglected in research. This is surprising since the gender-segregated household division is one of the main drivers of the 
gendered employment patterns that we observe. Moreover, the few studies have focused mainly on flexible working hours for mothers. In contrast, fathers' flexibility at the workplace should, in theory, be at least as important because a higher contribution of fathers to the household and to childcare would effectively relieve the mothers' burden. Therefore, we contribute to the literature on female employment and domestic work by answering the following question: How will fathers' and mothers' flexible working hours affect fathers' contributions and thus the gendered pattern of domestic work?

We tackle this research gap by looking specifically at couples where mothers are seeking to return to the labor force after spending an extended period of time out of the labor force taking care of their young children. This is an interesting group for two reasons. First, in Germany, most mothers drop out of the labor force for some time, so we examine an important transition in the female life course. For Germany, it has been shown that women having long-term employment interruptions due to taking care of children are very well educated and have mostly medium- or high-level education (vocational or university degree) (Diener et al., 2015; Rupp, 2013; Eurostat, 2019). Thus, this group of women with long employment interruptions is quite large and represents a specific target group for Labor market policies, particularly against the background of a scarcity of skilled workers. Second, the decision to re-enter the labor market usually goes along with the necessity to reorganize the household due to decreasing time budgets.

We interviewed 83 couples, employing a factorial survey experiment. In the experiment, hypothetical jobs with varying characteristics were offered to the still non-employed mothers. We asked both partners to rate these offers on several dimensions, in particular, to evaluate the distribution of domestic work and childcare between themselves and their partner that would be necessary if the female partner accepted a given offer. In our analysis, we focus on the male partners' evaluations. By this design, we are able to observe a change in the father's intention 
to contribute to domestic work and childcare due to the characteristics of the mothers' hypothetical job and the characteristics of the fathers' actual job. Moreover, the factorial survey design allows for the randomization of job offers, which rules out bias due to the selective search behavior of mothers that might arise if mothers, e.g., expect - wrongly or correctly that their husband will not contribute more to the household work or childcare. In this case, mothers may not search for certain jobs or may show reduced search behavior. Based on this design, we are the first to explore the change in fathers' intended contribution to domestic work as a causal reaction to the (hypothetical) re-employment of mothers.

The outline of this article is as follows. Section 2 provides an overview of the existing literature on flexible working hours and fathers' contribution to domestic work. In section 3, we discuss theoretical explanations for the influence of flexible working hours on fathers' contribution to domestic work and derive two hypotheses from theory. The dataset, as well as the operationalization of variables and the methods used, are described in section 4 . Section 5 includes the results of the logistic regression models, while section 6 provides further robustness checks and analysis. The results are summarized and discussed in section 7.

\section{Flexible working hours and fathers' contribution to domestic work}

A number of authors have investigated the impact of one partner's available time on both partners' contributions to domestic work, mostly focusing on the duration of the working time. For example, Rapoport and Le Bourdais (2008) find that the amount of working hours has a negative impact on the time spent parenting for both men and women and Bianchi et al. (2000) report that longer working hours of the mother increase the husband's share of domestic work. Several authors (e.g. van der Lippe, 2007; Voßemer and Heyne, 2019) found that if the husband's available time increases due to unemployment, this also leads to an increase in domestic work. 
Empirical evidence specifically regarding the effect of flexible working time on the division of domestic work is scarce. In general, flexible working time means that even if the duration of working time is fixed, the position or distribution of the hours varies over the day or the working week (Nijp et al., 2016; Beckmann and Cornelissen, 2014: 9). A key factor in this respect is whether the decision regarding the distribution of working time is made by the employer or by the employees themselves, in other words, whether the flexibility is managed by the employer or by the employees. In the case of employer-managed flexibility, the employer is free to make decisions regarding the number of days worked per week and/or which hours should be worked during the working day, e.g., in the context of shift work, emergency duty or standby duty. In the case of employee-managed flexibility, two versions can be distinguished (cf. Pierce and Newstrom, 1980). Flexitime is the name for a working-time regime with partially selfdetermined flexibility, in which the employee's presence is compulsory only during core working hours, but he or she is free to decide when the working day begins and ends. Typically, the employee has a working-time account in which working hours can be accumulated and reduced again. Free scheduling of working hours or trust-based working hours, on the other hand, means that there are no core working hours and there is no obligation to balance out hours over a certain period. Usually, the actual working hours are not recorded. This model is therefore characterized by the employee having full control over his or her working time. Some scholars have focused on "non-standard hours", i.e. employer-managed flexibility. While this form of temporal flexibility is mostly a by-product of employers' decisions regarding the arrangement of working hours over the day or week, its effect on the division of domestic work can still be informative. Silver and Goldscheider (1994) report that shift schedules increase the time spent on domestic work for women. Presser (1994) show that husbands with non-daytime or rotating shifts are more likely to perform household tasks. Similarly, Hewitt, Baxter and Mieklejohn (2014) find that not only do fathers in non-standard employment (irregular hours or night shifts) spend more time doing domestic work, but fathers whose partner works 
weekends or travels also spend increased time doing domestic work. According to Nock and Kingston (1988), when wives worked night shifts, fathers spent more time with the children. Brayfield (1995) analyzes the effect of fathers' and mothers' employment schedules on whether fathers took over childcare responsibilities. They found that while fathers reacted to the constraints imposed by mothers' schedules, among the temporal aspects of their own employment, only the non-day shifts positively impacted fathers' taking up of childcare responsibilities. Other aspects, including rotating shifts or working weekends, had no impact. Craig and Powell (2011) report that if fathers work non-standard hours, the share of domestic work and routine childcare performed by mothers' increases. When mothers themselves work nonstandard hours, there are no changes in the contribution of fathers to domestic work.

Very few studies focus on employee-managed flexibility. Hill et al. (2001) find that perceived temporal and spatial flexibility is, in general, positively related to the hours employees spend on household work and childcare. Noonan, Estes and Glass (2007) find that wives in jobs characterized by temporal flexibility contribute less to domestic work and their husbands more, while the pooled contribution stays the same. In contrast, their own temporal flexibility has no impact on fathers' contributions to domestic work or childcare. Baxter (2011) studies the impact of working hours and finds a negative impact of own working hours on parent-child interaction as well as a positive impact on the spouse's working hours. However, no impact on fathers' or mothers' time spent with children on parent-child interaction is found.

Our paper's aim is to contribute to this small stream of literature on working hours flexibility by presenting evidence from a quasi-experimental design and the specific case of the mother's return to employment after family-related breaks. While the literature also finds effects on domestic work due to employer-managed flexibility, we focus on employee-managed flexibility because the former also has negative side effects that might counterbalance any positive effects on domestic work (Martens et al., 1999). 


\section{Theoretical considerations and hypotheses}

From a practical perspective, flexible working hours allow parents to better synchronize their working time with their children's school or kindergarten schedule as well as their partners' working time (Bryan and Sevilla, 2017; Hallberg, 2003), thus helping them arrange their working time around their family duties (Noonan, Estes and Glass, 2007). In the context of mothers' return to work, fathers' temporal flexibility of working hours should enable them to support their partner's re-employment wishes more strongly by offering to take on higher shares of domestic work in case of re-employment.

Employee-controlled models of temporal flexibility, such as flextime and trust-based working hours, are often discussed as a means to reduce work-family conflict (Hildebrandt, 2006). The reasoning behind this is that there are predominantly three kinds of conflicts that might arise between work and family roles: strain-based, behavior-based and time-based conflicts (Greenhaus and Beutell, 1985). Flexible working schedules are aimed at specifically alleviating the last kind of conflict, i.e., time-based conflicts, that arise because the time spent at work cannot be devoted to the family and vice versa (Shockley and Allen, 2007). This is in line with time availability theory (Coverman, 1985; Hiller, 1984) that assumes that time constraints are the main determinant of domestic work. Thus, the shorter working hours of one partner will lead to a higher share of domestic work and, assuming a fixed amount of domestic work, a lower share for the other partner. However, fathers might find flexible working hours an equivalent but for several reasons a more attractive alternative than reduced working hours to increase available time (cf., Wheatley, 2017). First, temporal flexibility allows fathers to retain full-time working hours and therefore is more compatible with the male identity or the ideal worker norm (Kelly et al., 2010) than part-time work. Second, temporal flexibility should increase fathers' available household time without reducing income. The reason is that flexibility allows fathers to shift working time to time slots with less demands for domestic 
work, thereby freeing time slots when specific unpostponable needs arise, such as taking children to kindergarten, school or extracurricular activities.

However, there might also be disadvantages to flexible working hours, even if they are not as distinctive as the disadvantages of reduced hours. For example, Reimer (2015) argues that even if flexible working schedules exist in a firm, men might fear taking advantage of them because of the norm of the "ideal" or "unencumbered worker", and they expect penalties for noncompliance. Another reason is that family-friendly measures are sometimes perceived as targeted to mothers. Wheatly $(2017,2012)$ also points out some practical disadvantages, such as accessing workplace car parking when arriving later to work or arriving in time for meetings after taking the children to school.

Overall, available time should increase with flexible working hours, in the sense that the time that available to perform specific domestic tasks increases, mainly through the shifting of work time to time slots where demand for domestic work does not exist or is considerably lower. Thus, flexible working hours leave at least the possibility for fathers to increase their support for mother's re-employment by offering to take on a higher share of domestic work. Therefore, in line with time availability theory (Coverman, 1985; Hiller, 1984), our first hypothesis is as follows:

Hypothesis 1: Fathers'flexible working hours will increase their contribution to domestic work.

However, there are competing theories suggesting that more available time in the form of flexible working hours has no impact on fathers' contribution to domestic work. First, gender identity theories assume that domestic work is one way to express or "produce" one's gender (Berk, 1985; West and Zimmerman, 1987). From this perspective, performing specific tasks in the household is a way to confirm the female or male social identity, which is often referred to as "doing gender". These approaches lead to the assumption that fathers avoid domestic work because doing such work would jeopardize their socially constructed male identity. Second, the 
theories of "bargaining power" (Blood and Wolfe, 1960) or "relative resources" (Brines, 1994, 1993) assume that domestic work and childcare are cumbersome and produce disutility. Therefore, the partner with the most resources in terms of income, education or status will use these resources to negotiate a lower share of domestic work or childcare. The partner with the most resources is often the working husband, unless the wife's new job provides her with higher resources than her husband obtains through his job. However, this is not likely the case because the women in our study dropped out of the labor market for a considerable time period.

For our second hypothesis, we consider the employment situation of mothers, who also have the possibility to work flexible hours after re-employment. This flexibility, in turn, will increase the mothers' available time and, from the perspective of fathers, might decrease the perceived necessity to contribute more to domestic work. Therefore, we hypothesize the following:

Hypothesis 2: Mothers' flexible working hours will reduce fathers' contribution to domestic work.

\section{Data and Method}

\subsection{Data}

We use data from a factorial survey (see, e.g., Rossi and Anderson, 1982; Auspurg and Hinz, 2015) conducted in October 2014, where we presented hypothetical scenarios regarding reemployment of the female partner to both the male (employed) and female (non-employed) partners. However, because our hypotheses focus on fathers' contributions to domestic work, we used only the fathers' data in the main analysis. The data from the factorial survey were supplemented by a standardized survey. One partpresented to the fathers and mothers before, and one after the factorial survey. Participating couples were recruited from an earlier standardized survey of mothers who intended to gain re-employment after taking an extended break for family reasons. Among 491 couples in which the female partner participated in the 
survey, 83 couples agreed to participate in the factorial survey. The factorial survey presented to the couples contained eight short descriptions of hypothetical job offers (vignettes), whose characteristics (dimensions) were individually and randomly varied (see Figure 1 for a translated example). The same vignettes were presented to the male and female partner simultaneously on tablet computers with an interviewer present, thus preventing coordinated answering behavior. Each vignette contained eight dimensions of characteristics of the hypothetical job offer: (net) income, contractual working hours, personnel responsibility, career prospects, flexibility of working hours, type of contract (fixed- or limited-term), quality of the educational match and available childcare. See Table 1 for the number of levels for each dimension $^{1}$. We allocated vignettes randomly to the couples, so both partners evaluated the same eight job offers. Randomization ensured that per design, job characteristics were independent of the respondents' characteristics, thus uncoupling the quality and quantity of job offers from personal characteristics, including the respondents' human capital endowment. In addition, randomization neutralizes possible effects of the ordering of scenarios, such as learning or carry-over effects (Auspurg and Jäckle, 2017). Among others, this evaluation regarded how household work and childcare should be distributed between partners following the female partner's re-employment, both rated on a seven-point scale ranging from "all you" to "all your partner". In addition, each partner completed a questionnaire regarding the current division of domestic and childcare work, measured on the same scale, as well as the male socioeconomic characteristics and employment situation, most notably the possibility to work flexible hours.

\footnotetext{
${ }^{1}$ Out of all possible combinations of dimensions, we drew a D-efficient sample of 96 vignettes. The full set of scenarios (vignette universe) consists of all 512 possible combinations of the levels of the dimensions. Out of this vignette universe, we selected a D-efficient sample (12 blocks of 8 vignettes), which reduces the correlations between dimensions and maximizes the variance of each of the dimensions within the questionnaire versions. Furthermore, this procedure assures a "level balance" so that every category is distributed with approximately equal frequency (for details see Kuhfeld, Tobias and Garrat (1994); Atzmüller and Steiner (2010); Auspurg and Hinz (2015)).
} 
This experimental approach allows us to analyze the reaction of fathers to mothers' job offers. Relying on hypothetical job offers allows us to uncover the determinants of spousal supportive behavior, regardless of job offer acceptance. This is a major advantage because research based on mothers' realized returns to working life is selective, as it lacks information on the availability of alternative job offers. Presenting multiple job offers with individually varied dimensions to the same respondent enables us to estimate the exact effect of the individual job characteristic on decision making. In addition, this method provides data on an important subgroup that is usually hard to survey and for which taking up employment is a rare event. The independence of job quality from the mothers' characteristics untangles the selectivity of the job offers prevalent in real labor markets. Our factorial survey design experimentally standardizes the demand side of the labor market and thus allows us to observe the causal effects of job characteristics on the reaction of both partners. With our unique data set, we are thus able to analyze the role of male supportive behavior in response to female job offers.

\subsection{Operationalization and analytical strategy}

Our hypotheses focus on the division of domestic work within the surveyed couples, as stated by the father. Our main dependent variable is a measure that compares the (actual) pre-reemployment contribution of domestic work with the (hypothetical) post-re-employment contribution, both measured on a seven-point scale. More precisely, we construct an indicator variable that takes a value of 1 if the father's post-re-employment contribution surpasses the pre-re-employment value. In our data, we can distinguish between two areas of domestic work, household work and childcare, which allows us to use two complementary measures, both focusing on different aspects of domestic work. In the section on robustness checks and further analysis, we also use the amount of the father's current domestic work to investigate whether fathers' flexible working time already influences their current contribution and thus can have 
only a limited impact on their post-re-employment contribution. In this case, fathers might already have used their flexibility to increase their contribution to domestic work. In addition, we use the raw difference between the pre- and post-re-employment contributions as a sensitivity check. Furthermore, we conduct our main analysis from the mother's perspective to see whether the father's and the mother's own flexible working hours impact the amount of contribution to domestic work the mother expects from her male partner.

We are interested in two focal independent variables. First, fathers' flexible working time arrangement is taken from the supplementary father survey. We dichotomized a five-point measure for whether their employers enable them to use flexible working hours to provide a family-friendly work environment. We dichotomized this measure, where we counted agreement and absolute agreement as an indicator for flexible working time arrangements. Notably, the variable measures not the actual use of flexible working hours but whether fathers believe that such working time arrangements are available to them in their workplace. This is an advantage because our measure allows for the take up of flexible working hours by fathers who during the wife's current parental leave do not (yet) make use of their firm's policy. Second, mothers' flexible working time arrangement is taken from the factorial survey. Here, the hypothetical job offer scenario distinguishes between jobs associated with a) fixed working schedules, b) flexible working hours, c) flexible working hours combined with working time accounts, and d) flexible working hours combined with working time accounts and home office (see Table 1 in the Appendix). We construct a dummy indicator variable that distinguishes between working fixed working hours (option a) from arrangements that include flexible working hours (options b, c and d).

The main dependent variable is based on the difference between the father's contributions before and after the mother's re-employment. While we need to measure the contribution before only once, the contribution after is taken from the father's response to the eight hypothetical 
job offer scenarios. This presents us with a hierarchical data structure, where eight different measures of the dependent variable are nested within each respondent. To test our hypotheses, we employ logistic regression and apply standard errors clustered at the level of the father (Rogers, 1994) $)^{2}$. All displayed coefficients are average marginal effects.

We control for two kinds of independent variables. First, we control for variables that vary within the respondent because they refer to characteristics of the mother's job offer scenario from the vignette (vignette dimensions), as displayed in Table 1. Second, we control for characteristics that are constant within the respondents. These are on the one hand fathers' socioeconomic and other characteristics, such as age, years of education, employment status and net income and fathers' employment-related gender role attitudes as controls. On the other hand, characteristics constant within the respondent include characteristics of the couple, such as relationship duration, duration of the mother's employment interruption, number of children, age of the youngest child, availability of formal or informal support regarding various dimensions of domestic work and whether agreements among the partners exist ${ }^{3}$, how family and housework may change and what the partners' respective contributions are, when the mother is working again.

\section{Empirical Analysis}

\subsection{Sample description}

Before we report the results of our empirical analysis, we present a description of our analytical sample. The sample includes 64 fathers with 506 observations ( 8 vignette evaluations each). In

\footnotetext{
${ }^{2}$ Usually multilevel modelling, but only if there is a cross-level interaction; otherwise, we adopt OLS.

${ }^{3}$ Fathers were asked to indicate whether the following agreements with their spouses exist: (1) I would do more housework (cooking, cleaning, laundry), (2) I would take over more care time for the children, (3) I would reduce my hours and (4) I would support the care of relatives. Furthermore, the partners were asked whether they had.
} 
Table A2 (see Appendix), we report information on the number of cases, means, smallest and largest observed values, cardinal variables and standard deviations.

Starting with the sociodemographic composition, respondents are, on average, slightly older than 45 years and comparatively highly educated with approximately 12 years of education. The youngest child is, on average, more than 8 years old, and the average duration of the relationship between the father and the mother is more than 16 years. Regarding employment situation, the fathers in our sample obtain, on average, a net income of 3,853 Euro, 97 percent are employed fulltime, and average working hours are approximately 44.7 hours per week. Approximately half of our respondents work in firms where flexible working hours are available as a family-friendly policy. While the sample is clearly skewed toward older and welleducated fathers, the high share of workers able to work flexible hours corresponds to the high prevalence of such policies in Germany in general but especially among the more highly qualified workforce (Zapf and Brehmer, 2010). Turning to descriptive evidence for the main and supplementary dependent variables, fathers' actual pre-re-employment contributions to household work and childcare are measured on a seven-point scale, reverse coded to range from 1 (all my wife) to 7 (all myself). The average contribution to household work is 2.59 . This means that, on average, fathers state that they contribute significantly less to household work than their respective partners. With 2.80, the value for childcare is slightly higher but also below the value of 4 that would indicate equity. After the hypothetical re-employment of their female partners, fathers, on average, are willing to contribute more to both household work and childcare, as indicated by values of approximately 3.5 for both kinds of domestic work. Turning to the main dependent variable of our analysis below and in line with the already mentioned figures, there is a relatively high share of fathers who would contribute more after their female partner's re-employment than they do currently. In 62 percent of all observations, we find an 
increase in the contribution to household work following the mother's re-employment. The respective value for childcare is significantly lower, but still at 51 percent.

\subsection{Multivariate results}

Figure 1 displays the results of our hypotheses tests. We start with hypothesis 1 , stating that fathers' flexible working schedules will lead to an increase in their contribution to domestic work. If fathers work in firms where flexible working schedules are available as a familyfriendly workplace measure, this raises the probability that they are willing to increase their contribution to childcare by 23.1 percentage points. Because the average probability of increasing the childcare contribution is 51 percent, this value is not only significant but also of quite substantial magnitude. Regarding household work, the empirical evidence is not as clear. The coefficient of fathers' flexible working schedule is not statistically significant, but following the recent methodological debate on statistical versus social significance (Bernardi, Chakhaia and Leopold, 2017), we should not interpret this as indicative of a null effect. Instead, with 9.7 percent, it is of substantial size and in the hypothesized direction, thus giving at least some support to hypothesis 1 . In all, this leaves us with empirical results that support hypothesis 1 regarding the contribution to childcare and provide mixed evidence regarding household work. 
Figure 1: Effect of fathers' and mothers' flexible working schedules on their contribution to domestic work (Hypotheses 1 and 2)

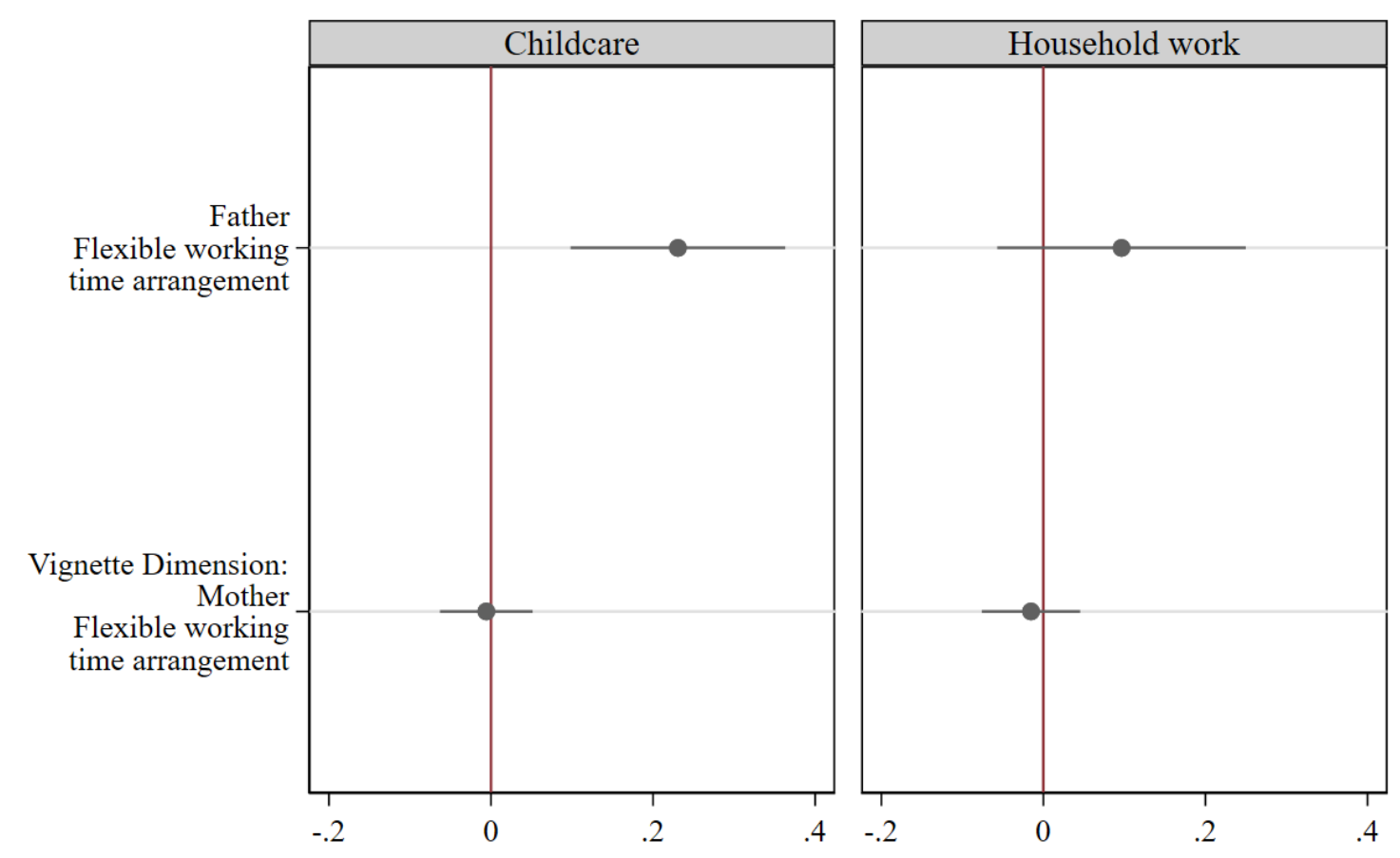

512 / 506 Vignette evaluations, 64 male respondents, Control variables:

Vignette dimensions: hourly wage, working hours, flexible WTA, qualification fit, staff responsibility, caeer prospects, fixed term contract, company childcare Sociodemographics: years of education, age of respondent

Household and relationship: relationship duration, duration of the woman's interruption of employment, number of children, age of youngest child

Male labor market status: working hours, flexible WTA, net income, occupational status

Other: Gender norms, domestic help, partnership arrangements 
Table 1: Full regression results for hypotheses 1 and 2

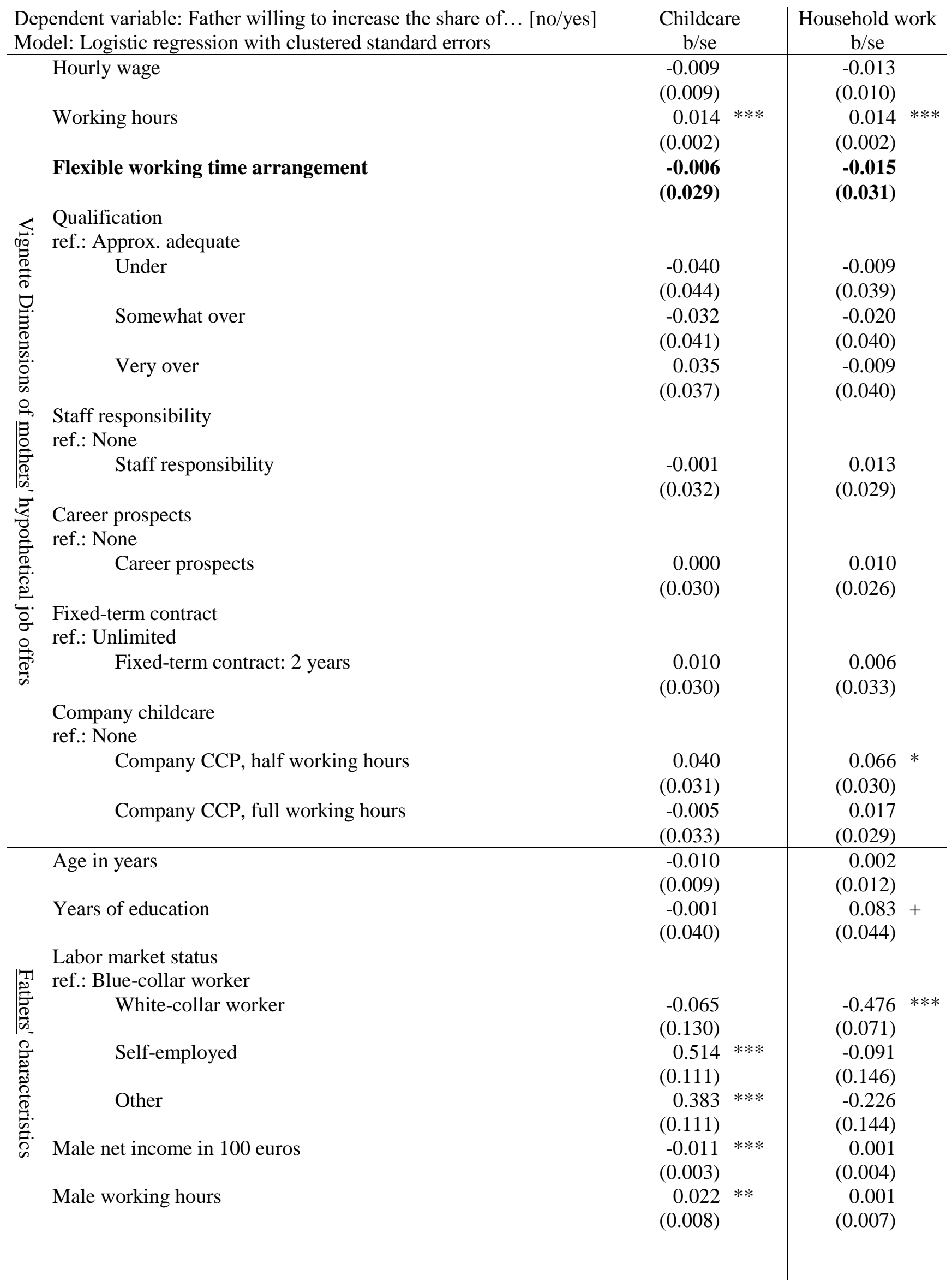


Dependent variable: Father willing to increase the share of... [no/yes]

Model: Logistic regression with clustered standard errors

Male flexible working time arrangements

ref.: No

Yes

\begin{tabular}{l|l} 
Childcare & Household work
\end{tabular} $\mathrm{b} / \mathrm{se}$ $\mathrm{b} / \mathrm{se}$

Does not apply (e.g., self-employed)

\begin{tabular}{r}
$\mathbf{0 . 2 3 1}$ \\
$(\mathbf{0 . 0 6 8})$ \\
$-0.327 * * *$ \\
$(0.049)$ \\
\hline 0.012 \\
$(0.009)$
\end{tabular}

Relationship duration

$(0.009)$

ref.: under 5 years

5 to 15 years

$(0.113)$

0.142

Longer than 15 years

$(0.155)$

0.035

Already employed again

$(0.141)$

$-0.006$

$(0.074)$

(0.078)

$-0.075$

$(0.355)$

0.003

$(0.009)$

Number of children in the household

Age of youngest child in the household

ref.: Younger than 7 years

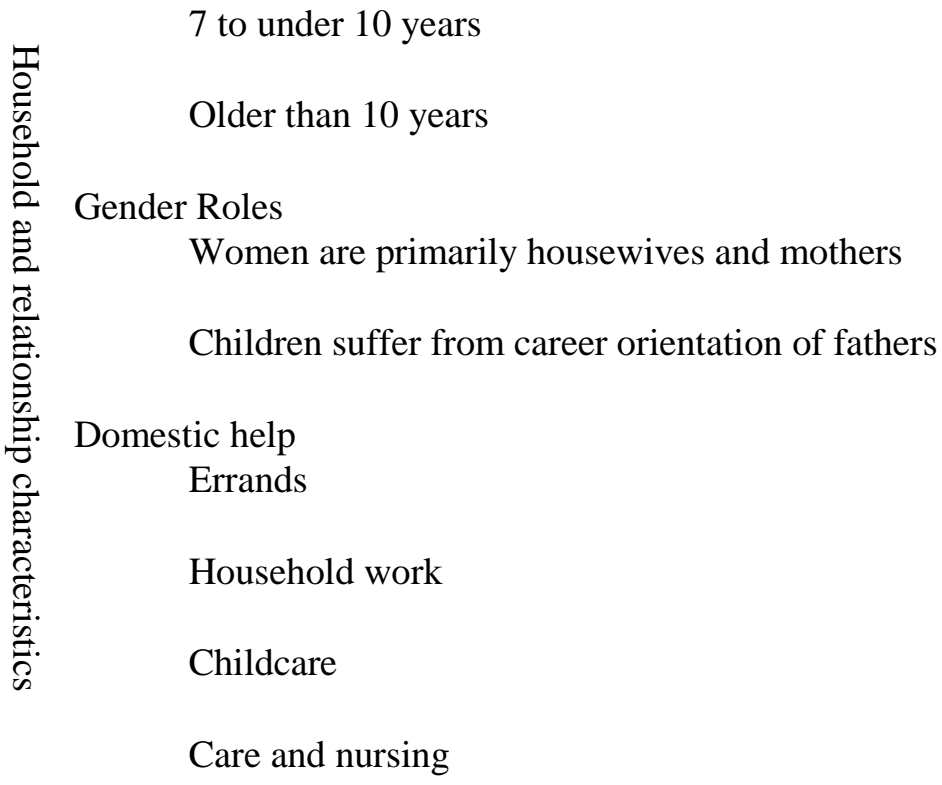

$-0.269$

$-0.260 * *$

$(0.071)$

$(0.099)$

$-0.499 * * *$

(0.082)

$-0.277+$

(0.145)

0.048

0.011

$(0.047)$

$(0.046)$

0.037

0.048
$(0.045)$

(0.044)

$-0.411 * * *$

(0.073)

$-0.427 * *$

$(0.147)$

$0.196+$

0.126

(0.106)

$(0.124)$

$-0.092$

0.005

$(0.083)$

$(0.092)$

$0.511 * * *$

$-0.001$

(0.029)

(0.197)

Agreements between partners

No agreement

$-0.140$

0.159

$(0.142)$

$(0.156)$

Increase household work

0.042

$-0.033$

$(0.165)$

$(0.171)$

Increase own childcare

$-0.029$

0.056

(0.114)

$(0.129)$

Reduce working hours

$-0.177+$

$-0.007$

$(0.101)$

$(0.149)$

Help with caring for relatives

Other 


\begin{tabular}{lc|c}
$\begin{array}{l}\text { Dependent variable: Father willing to increase the share of... [no/yes] } \\
\text { Model: Logistic regression with clustered standard errors }\end{array}$ & $\begin{array}{c}\text { Childcare } \\
\text { b/se }\end{array}$ & $\begin{array}{c}\text { Household work } \\
\text { b/se }\end{array}$ \\
\hline Vignette-Evaluations & $(0.153)$ & $(0.121)$ \\
\hline Fathers & 506 & 512 \\
Pseudo-R-squared & 64 & 64 \\
Average marginal effects, clustered standard errors in parentheses $(+\mathrm{p}<0.10, * \mathrm{p}<0.05, * * \mathrm{p}<0.01, * * * \mathrm{p}<0.001)$.
\end{tabular}

Turning to hypothesis 2, we find that the coefficient of mothers' flexible working schedule following re-employment on fathers' childcare contribution is statistically insignificant and with a value of -0.006 substantially not significant as well. Similarly, the coefficient of household work is -0.015 and statistically and substantially nonsignificant. This result means that the fathers in our sample are neither less nor more likely to increase their contribution to domestic work if the mothers can work flexible hours. Therefore, we find no support for hypothesis 2 in the data. It is noteworthy that in contrast to the dimension of flexible working hours, the absolute number of working hours associated with a job offer has a positive and statistically significant effect on the probability of contributing to domestic work. This holds for both childcare and household work, where the coefficients are very similar and indicate an increase of 1.4 percentage points per working hour, respectively.

\section{Robustness checks and further analysis}

In our main analysis, we used a dichotomized variable to analyze the change in fathers' domestic work contribution. This allows for a clear interpretation of the resulting coefficients in terms of percentage points and condenses the available information because it treats small and large changes the same. As a robustness check, we also used the raw before- and afterdifference of the two seven-point scales as the dependent variable (see Table A3 in the Appendix). The results are very similar to those of the main analysis. We find that fathers increase their contribution by, on average, 0.73 points with respect to childcare, and this 
increase is significantly different from zero. For household work, we find a smaller but still positive coefficient of 0.43 that is statistically nonsignificant.

As a second robustness check, we inspected whether fathers who are able to work flexible hours are already contributing more to domestic work, even before mothers take up re-employment. Such fathers could be using the higher amount of available time to contribute to domestic work irrespective of the labor market status of their wives. If this were the case, we would underestimate the overall effect of flexible working hours on a father's contribution to domestic work. From Table A3 in the Appendix, we can see that contrary to our expectations, fathers with flexible working hours invest less in childcare when their wives are not gainfully employed. The coefficient is -0.772 points on the seven-point scale and statistically significant. The respective coefficient for household work is much smaller, with $-0,242$ points and statistically nonsignificant. Thus, at least for childcare, the empirical evidence indicates that flexible working hours lead to a significantly lower investment of fathers in childcare when their spouses are not gainfully employed. This result is in line with recent empirical evidence that finds longer working hours for male workers working flexible hours (Lott and Chung, 2016). However, in the case of their partner's re-entry into employment, fathers with flexible working hours are willing to increase their contribution, surpassing fathers with standard working hours, as indicated by our main results.

Finally, our analysis takes the viewpoint of the fathers and analyzes their willingness to contribute to domestic work. As documented in Table A4 in the Appendix, the mothers' expectation that their partner will provide an increased contribution to household work is approximately 15 percentage points higher if the partner is able to work flexible hours, where the coefficient is statistically significant. The increase of 8 percentage points for childcare is not significantly different from zero, however. With regard to mothers' evaluation of their own situation, the perspective of working flexible hours has only a very small and nonsignificant 
effect on what they expect from their partners. This result therefore mirrors the fathers' actual willingness to contribute to childcare and household work, respectively.

\section{Conclusions}

When looking at the labor market integration of mothers, the reconciliation of paid work and domestic labor is still a crucial question. To date, existing research has concentrated mostly on the role of work conditions, specifically work flexibility, of mothers' employment. However, theoretically, as well as in public debate, the role of fathers' working conditions should also be important. For example, in Germany, parental leave regulations are also targeted at men, who should contribute to childcare.

However, the role of fathers' work flexibility in the labor market re-entry of mothers has not yet been examined. Consequently, in this paper, we asked how the flexible working hours of fathers affect the gender pattern of domestic work and childcare. We found that flexible working hours lead fathers to make a higher contribution to domestic work, especially regarding childcare. To a smaller degree, this might also be true for household work, but our results are not conclusive. In contrast, the fathers' willingness to contribute to either form of domestic work did not depend on whether the mothers were able to work flexible hours after labor market re-entry.

The main strength of our analysis can be seen in the experimental approach, which allows us to estimate causal effects of the mother's conditions of re-employment, thereby eliminating bias that would occur because mothers with unsupportive partners or inflexible occupations would not seek employment at all. Nevertheless, our innovative research design also has some disadvantages. First, we observe only hypothetical decisions because vignettes are not real job offers. However, it is widely agreed that such hypothetical scenarios give a good estimation of real behavior as long as the situation is close to the respondent's real world and experiences 
(Auspurg and Hinz, 2015). Because our sample consists of mothers trying to re-enter the labor market, we can assume that the hypothetical scenarios were seen as realistic enough (see Drasch, 2019 for empirical support for this assumption). Second, the father's working schedules are not part of the randomized experimental design. On the one hand, in contrast to mothers' flexible working hours, for this variable, we are faced with considerably lower statistical power, determined by the number of individuals and not vignettes in our sample. This might explain why we find a positive coefficient of at least medium size for the effect of fathers' flexible working hours on household work that is, however, not statistically different from zero. On the other hand, this exclusion from randomization makes the respective coefficient more vulnerable to unobserved heterogeneity. For example, we might expect fathers who tend to contribute more to domestic work to select into firms that offer flexible working hours. However, even in that case, flexible working hours are still important because they provide the opportunity structure for fathers willing to engage in (more) domestic work. Fourth, the degree to which our results apply to fathers, in general, depends on whether the population under analysis is less or more likely to react to flexible working hours by contributing to domestic work. In the preceding analysis, we analyzed fathers with an average age of 46 , whose partners have been out of the labor force for a considerable amount of time and whose youngest children are, on average, eight years old. We would argue that this population should be less willing to increase their contribution to domestic work, given these long employment interruptions.

Keeping these limitations in mind, our results indicate that policymakers and firms should be encouraged to foster the implementation and use of flexible working hours, not only for the female but also for the male workforce. Such policies can contribute to a more balanced distribution of domestic work between husbands and wives. When mothers take extended breaks from employment to care for children, they typically face difficulties reconciling their responsibilities for domestic work with gainful employment. Especially in these circumstances, 
it seems effective to foster the provision of flexible working hours policies among firms and thus enable fathers to facilitate mothers' re-employment efforts, for example, by sharing a larger part of the domestic work responsibilities. 


\section{References}

Atzmüller, C. and Steiner, P. M. (2010). Experimental Vignette Studies in Survey Research. Methodology, 6, 128-138.

Auspurg, K. and Hinz, T. (2015). Factorial Survey Experiments. Thousand Oaks, Calif.: Sage.

Auspurg, K. and Jäckle, A. (2017). First equals most important? Order effects in vignettebased measurement. Sociological Methods \& Research, 46, 490-539.

Baxter, J. (2011). Flexible Work Hours and Other Job Factors in Parental Time with Children. Social Indicators Research, 101, 239-242.

Beckmann, M. and Cornelissen, T. (2014). Self-Managed Working Time and Employee Effort: Microeconometric Evidence.

Berk, S. F. (1985). The Gender Factory: The Apportionment of Work in American Households. New York: Plenum.

Bernardi, F., Chakhaia, L. and Leopold, L. (2017). 'Sing Me a Song with Social Significance'. The (Mis)Use of Statistical Significance Testing in European Sociological Research. European Sociological Review, 33, 1-15.

Bianchi, S. M., Milkie, M. A., Sayer, L. C. and Robinson, J. P. (2000). Is Anyone Doing the Housework? Trends in the Gender Division of Household Labor*. Social Forces, 79, 191228.

Blood, R. O. and Wolfe, D. M. (1960). Husbands and Wives. The Dynamics of Married Living. New York: Free Press.

Blossfeld, H.-P. (1997). Women's Part-Time Employment and the Family Cycle: A CrossNational Comparison. In Blossfeld, H.-P. and Hakim, C. (Eds.). Between equalization and marginalization: Women working part-time in Europe and the United States of America. Oxford and New York: Oxford University Press, pp. 315-324.

Brayfield, A. (1995). Juggling Jobs and Kids. The Impact of Employment Schedules on Fathers' Caring for Children. Journal of Marriage and the Family, 57, 321-332.

Brines, J. (1993). The Exchange Value of Housework. Rationality and Society, 5, 302-340.

Brines, J. (1994). Economic Dependency, Gender, and the Division of Labor at Home. American Journal of Sociology, 100, 652-688.

Bryan, M. L. and Sevilla, A. (2017). Flexible working in the UK and its impact on couples' time coordination. Review of Economics of the Household, 15, 1415-1437.

Coverman, S. (1985). Explaining Husbands' Participation in Domestic Labor. The Sociological Quarterly, 26, 81-97.

Craig, L. and Powell, A. (2011). Non-standard work schedules, work-family balance and the gendered division of childcare. Work, Employment and Society, 25, 274-291.

Dechant, A. and Blossfeld, H.-P. (2015). Changes in the division of labor within highly educated German couples when the first child is born. ZfF-Zeitschrift für Familienforschung/Journal of Family Research, 27, 373-396.

Dechant, A., Rost, H. and Schulz, F. (2014). Die Veränderung der Hausarbeitsteilung in Paarbeziehungen. Ein Überblick über die Längsschnittforschung und neue empirische Befunde auf Basis der pairfam-Daten. ZfF-Zeitschrift für Familienforschung/Journal of Family Research, 26, 144-168.

Diener, K., Götz, S., Schreyer, F., Stephan, G., Lenhart, J., Nisic, N. and Stöhr, J. (2015). Rückkehr ins Berufsleben nach familienbedingter Unterbrechung. IAB-Forschungsbericht, 7/2015, 1-97.

Drasch, K. (2013). Educational attainment and family-related employment interruptions in Germany: Do changing institutional settings matter? European Sociological Review, 29, 981-995. 
Drasch, K. (2019). Behavioral Intentions, Actual Behavior and the Role of Personality Traits. Evidence from a Factorial Survey Among Female Labor Market Re-Entrants. methods, data, analyses, 13, 267-290.

Eurostat (2019). Reconciliation of work and family life - statistics. https://ec.europa.eu/eurostat/statisticsexplained/index.php?title=Reconciliation_of_work_and_family_life__statistics\#Career_break_for_childcare.

Evertsson, M., Grunow, D. and Aisenbrey, S. (2016). Work interruptions and young women's career prospects in Germany, Sweden and the US. Work, Employment and Society, 30, 291-308.

Frodermann, C., Müller, D. and Abraham, M. (2013). Determinanten des Wiedereinstiegs von Müttern in den Arbeitsmarkt in Vollzeit oder Teilzeit. KZfSS Kölner Zeitschrift für Soziologie und Sozialpsychologie, 65, 645-668.

Greenhaus, J. H. and Beutell, N. J. (1985). Sources of Conflict between Work and Family Roles. The Academy of Management Review, 10, 76-88.

Grunow, D., Schulz, F. and Blossfeld, H.-P. (2012). What determines change in the division of housework over the course of marriage? International Sociology, 27, 289-307.

Hallberg, D. (2003). Synchronous leisure, jointness and household labor supply. Labour Economics, 10, 185-203.

Hewitt, B., Baxter, J. and Mieklejohn, C. (2014). Non-standard employment and fathers' time in household labour. Journal of Family Studies, 18, 175-186.

Hildebrandt, E. (2006). Balance between work and life - new corporate impositions through flexible working time or opportunity for time sovereignty? European Societies, 8, 251272.

Hill, E. J., Hawkins, A. J., Ferris, M. and Weitzman, M. (2001). Finding an Extra Day a Week: The Positive Influence of Perceived Job Flexibility on Work and Family Life Balance. Family Relations, 50, 49-58.

Hill, E. J., Märtinson, V. K., Ferris, M. and Baker, R. Z. (2004). Beyond the Mommy Track: The Influence of New-Concept Part-Time Work for Professional Women on Work and Family. Journal of Family and Economic Issues, 25, 121-136.

Hiller, D. V. (1984). Power dependence and division of family work. Sex Roles, 10, 1003 1019.

Kelly, E. L., Ammons, S. K., Chermack, K. and Moen, P. (2010). Gendered Challenge, Gendered Response: Confronting the Ideal Worker Norm in a White-Collar Organization. Gender \& Society, 24, 281-303.

Kuhfeld, W., Tobias, R. and Garrat, M. (1994). Efficient experimental design with marketing research applications. Journal of Marketing Research, 31, 545-557.

Kühhirt, M. (2012). Childbirth and the Long-Term Division of Labour within Couples. How do Substitution, Bargaining Power, and Norms affect Parents' Time Allocation in West Germany? European Sociological Review, 28, 565-582.

Lott, Y. and Chung, H. (2016). Gender Discrepancies in the Outcomes of Schedule Control on Overtime Hours and Income in Germany. European Sociological Review, 32, 752-765.

Martens, M. F. J., Nijhuis, F. J. N., Van Boxtel, M. P. J. and Knottnerus, J. A. (1999). Flexible work schedules and mental and physical health. A study of a working population with non-traditional working hours. Journal of Organizational Behavior, 20, 35-46.

Nijp, H. H., Beckers, D. G. J., van de Voorde, K., Geurts, S. A. E. and Kompier, M. A. J. (2016). Effects of New Ways of Working on Work Hours and Work Location, Health and Job-Related Outcomes. Chronobiology International, 33, 604-618.

Nock, S. L. and Kingston, P. W. (1988). Time With Children: The Impact of Couples' WorkTime Commitments*. Social Forces, 67, 59-85. 
Noonan, M. C., Estes, S. B. and Glass, J. L. (2007). Do Workplace Flexibility Policies Influence Time Spent in Domestic Labor? Journal of Family Issues, 28, 263-288.

Pierce, J. L. and Newstrom, J. W. (1980). Toward A Conceptual Clarification Of Employee Responses To Flexible Working Hours: A Work Adjustment Approach. Journal of Management, 6, 117-134.

Presser, H. B. (1994). Employment Schedules Among Dual-Earner Spouses and the Division of Household Labor by Gender. American Sociological Review, 59, 348-364.

Rapoport, B. and Le Bourdais, C. (2008). Parental Time and Working Schedules. Journal of Population Economics, 21, 903-932.

Reimer, T. (2015). Working time arrangements and family time of fathers: How work organization(s) shape fathers' opportunities to engage in childcare. Management Revue, 26, 227-252.

Rogers, W. (1994). Regression standard errors in clustered samples. Stata Technical Bulletin, 3.

Rosenfeld, R. A. and Birkelund, G. E. (1995). Women's Part-Time Work. A Cross-National Comparison. European Sociological Review, 11, 111-134.

Rosenfeld, R. A., Trappe, H. and Gornick, J. C. (2004). Gender and Work in Germany. Before and After Reunification. Annual Review of Sociology, 30, 103-124.

Rossi, P. H. and Anderson, A. B. (1982). The factorial survey approach: An introduction. In Rossi, P. and Nock, S. (Eds.). Measuring Social Judgments: The Factorial Survey Approach. Beverly Hills, CA: Sage, pp. 15-67.

Rupp, M. (2013). Die Berufsrückkehr von Müttern unter den Bedingungen des neuen Elterngeldes: Broschüre mit zentralen Studienergebnissen. Staatsinstitut für Familienforschung an der Universität Bamberg (ifb). ifb-Materialien, 1-2013.

Sayer, L. C. (2005). Gender, Time and Inequality: Trends in Women's and Men's Paid Work, Unpaid Work and Free Time. Social Forces, 84, 285-303.

Schober, P. S. (2011). The Parenthood Effect on Gender Inequality: Explaining the Change in Paid and Domestic Work When British Couples Become Parents. European Sociological Review, 29, 74-85.

Schober, P. S. (2013). Maternal labor market return and domestic work after childbirth in Britain and Germany. Community, Work \& Family, 16, 307-326.

Schulz, F. (2010). Verbundene Lebensläufe. Wiesbaden: VS Verlag für Sozialwissenschaften.

Shockley, K. M. and Allen, T. D. (2007). When flexibility helps. Another look at the availability of flexible work arrangements and work-family conflict. Journal of Vocational Behavior, 71, 479-493.

Silver, H. and Goldscheider, F. (1994). Flexible Work and Housework: Work and Family Constraints on Women's Domestic Labor*. Social Forces, 72, 1103-1119.

van der Lippe, T. (2007). Dutch workers and time pressure: Household and workplace characteristics. Work, Employment and Society, 21, 693-711.

West, C. and Zimmerman, D. H. (1987). Doing Gender. Gender \& Society, 1, 125-151.

Wheatley, D. (2012). Work-life balance, travel-to-work, and the dual career household. Personnel Review, 41, 813-831.

Wheatley, D. (2017). Employee Satisfaction and Use of Flexible Working Arrangements. Work, Employment and Society, 31, 567-585.

Zapf, I. and Brehmer, W. (2010). Arbeitszeitkonten haben sich bewährt. Nürnberg. 


\section{Appendix}

Table A1: Dimensions and categories used in the scenarios.

Dimension

Level

\begin{tabular}{|c|c|c|c|c|}
\hline & 1 & 2 & 3 & 4 \\
\hline 1 Income (net) ${ }^{4}$ & \multicolumn{4}{|c|}{$-15 \%-10 \%-5 \% 0 \%+5 \%+10 \%+15 \%$} \\
\hline $\begin{array}{l}2 \text { Working } \\
\text { hours }\end{array}$ & 10 & 20 & 30 & 40 \\
\hline $\begin{array}{l}3 \text { Flexible } \\
\text { working } \\
\text { schedules }\end{array}$ & $\begin{array}{l}\text { Fixed working } \\
\text { schedules }\end{array}$ & $\begin{array}{l}\text { flexible working } \\
\text { hours }\end{array}$ & $\begin{array}{l}\text { Working time } \\
\text { accounts and } \\
\text { flexible working } \\
\text { hours }\end{array}$ & $\begin{array}{l}\text { Working time } \\
\text { accounts, flexible } \\
\text { working hours, } \\
\text { and home office }\end{array}$ \\
\hline $\begin{array}{l}4 \text { Qualification } \\
\text { of the mother }\end{array}$ & $\begin{array}{l}\text { the position is } \\
\text { under the } \\
\text { professional skills }\end{array}$ & Adequate & $\begin{array}{l}\text { the position } \\
\text { somewhat fits the } \\
\text { professional skills }\end{array}$ & $\begin{array}{l}\text { the position fits } \\
\text { the professional } \\
\text { skills }\end{array}$ \\
\hline $\begin{array}{l}5 \text { Staff } \\
\text { responsibility }\end{array}$ & $\begin{array}{l}\text { No staff } \\
\text { responsibility }\end{array}$ & $\begin{array}{l}\text { With staff } \\
\text { responsibility }\end{array}$ & & \\
\hline $\begin{array}{l}6 \text { Career } \\
\text { prospects }\end{array}$ & $\begin{array}{l}\text { No career } \\
\text { prospects }\end{array}$ & $\begin{array}{l}\text { With career } \\
\text { prospects }\end{array}$ & & \\
\hline $\begin{array}{l}7 \text { Fixed-term } \\
\text { contract }\end{array}$ & $\begin{array}{l}\text { Permanent } \\
\text { contract }\end{array}$ & $\begin{array}{l}\text { Limited to } 2 \\
\text { years }\end{array}$ & & \\
\hline 8 Childcare & $\begin{array}{l}\text { No (fee-based) } \\
\text { company } \\
\text { childcare }\end{array}$ & $\begin{array}{l}\text { No (fee-based) } \\
\text { company } \\
\text { childcare }\end{array}$ & $\begin{array}{l}\text { (Fee-based) } \\
\text { company } \\
\text { childcare for half } \\
\text { of the working } \\
\text { hours }\end{array}$ & $\begin{array}{l}\text { (Fee-based) } \\
\text { company } \\
\text { childcare for } \\
\text { complete working } \\
\text { hours }\end{array}$ \\
\hline
\end{tabular}

\footnotetext{
${ }^{4}$ Income was presented in Euros and was calculated form the vignette level, which was a factor of 85 / 90 / 95 / $100 / 105 / 110 / 115$ percent of the last gross income of the mother mentioned in the previous telephone survey of the perspective re-entry project.
} 
Table A2: Descriptive statistics

fathers

variable vignettes persons mean sd p50 min max

Contribution to childcare

Pre-re-employment

Post re-employment

$\begin{array}{ll}506 & 64 \\ 506 & 64\end{array}$

difference (post minus pre)

$506 \quad 64$

Increased contribution (yes / no)

506

64

Contribution of household work

Pre-re-employment

\begin{tabular}{ll}
512 & 6 \\
512 & 6 \\
512 & 6 \\
\hline
\end{tabular}

Post re-employment

64

difference (post minus pre)

64

2.80

$\begin{array}{llll}0.80 & 3 & 1 & 4\end{array}$

Increased contribution (yes / no)

$\begin{array}{lll}\text { Age of respondent } & 64 \\ \text { Years of education } & \text { Marital status }\end{array}$

64

64

3.49

$\begin{array}{llll}1.00 & 4 & 1 & 6\end{array}$

64

$\begin{array}{lllll}\mathbf{0 . 7 1} & 1.16 & 1 & -3 & 4\end{array}$

$\begin{array}{lllll}\mathbf{0 . 5 1} & 0.50 & 1 & 0 & 1\end{array}$

$\begin{array}{ll}\text { Single } & 64\end{array}$

Married

64

$\begin{array}{lllll}2.59 & 1.22 & 2 & 1 & 7\end{array}$

Civil partnership

64

$\begin{array}{lllll}\mathbf{3 . 5 1} & 1.09 & 4 & 1 & 6\end{array}$

Divorced/widowed

64

Duration of relationship (in years)

64

64

$\begin{array}{lllll}\mathbf{0 . 9 1} & 1.45 & 1 & -6 & 4\end{array}$

Number of children in the household

$\begin{array}{rcccc}\mathbf{0 . 6 2} & 0.49 & 1 & 0 & 1 \\ \mathbf{4 5 . 7 0} & 5.51 & 47 & 31 & 62 \\ \mathbf{1 2 . 1 3} & 1.35 & 13 & 9 & 13\end{array}$

Age of youngest child in the household

64

12.13

$\begin{array}{llll}1.35 & 13 & 9 & 13\end{array}$

Care activities (yes/no)

Domestic help: Household work (yes/no)

64

$\begin{array}{lllll}\mathbf{0 . 0 5} & 0.21 & 0 & 0 & 1 \\ \mathbf{0 . 9 4} & 0.24 & 1 & 0 & 1 \\ \mathbf{0 . 0 0} & 0.00 & 0 & 0 & 0\end{array}$

Domestic help: Childcare (yes/no)

Full-time employment (yes/no)

Part-time employment (yes/no)

Occupational position

$$
\text { Blue-collar }
$$

White-collar

Military

Civil servant/Judge

Self-Employed: Freelance profession

Self-Employed: Service sector

64

0.02

64

16.27

64

64

16.27
2.06

$\begin{array}{llll}0.13 & 0 & 0 & 1\end{array}$

Other occupation

Temporary employment (yes/no)

Fixed-term work (yes/no)

Weekly working hours

Weekly working hours over 40 hours (yes/no)

Monthly net income in 100 Euros

Flexible working time arrangements (yes/no)

\begin{tabular}{lrrccc}
64 & $\mathbf{0 . 0 8}$ & 0.27 & 0 & 0 & 1 \\
64 & $\mathbf{0 . 7 5}$ & 0.44 & 1 & 0 & 1 \\
64 & $\mathbf{0 . 0 3}$ & 0.18 & 0 & 0 & 1 \\
64 & $\mathbf{0 . 0 2}$ & 0.13 & 0 & 0 & 1 \\
64 & $\mathbf{0 . 0 6}$ & 0.24 & 0 & 0 & 1 \\
64 & $\mathbf{0 . 0 5}$ & 0.21 & 0 & 0 & 1 \\
64 & $\mathbf{0 . 0 2}$ & 0.13 & 0 & 0 & 1 \\
56 & $\mathbf{0 . 0 2}$ & 0.13 & 0 & 0 & 1 \\
56 & $\mathbf{0 . 0 4}$ & 0.19 & 0 & 0 & 1 \\
64 & $\mathbf{4 4 . 7 0}$ & 6.51 & 45 & 30 & 60 \\
64 & $\mathbf{0 . 6 1}$ & 0.49 & 1 & 0 & 1 \\
64 & $\mathbf{3 8 . 5 3}$ & 17.05 & 35 & 3.2 & 95 \\
64 & $\mathbf{0 . 4 8}$ & 0.50 & 0 & 0 & 1 \\
\hline
\end{tabular}


Figure A1. A translated sample scenario for men, with the varied dimensions highlighted

If your partner accepts the job offer, she receives a monthly gross income of about $\mathbf{1 , 0 0 0}$ Euros. The job is $\mathbf{2 0}$ hours a week and provides flexible working hours. As far as the requirements are concerned, the position somewhat fits the professional skills of your partner. The position does not include any personnel responsibility, offers career opportunities and is open-ended. Childcare facilities are available on site.

How attractive do you think this job offer is?

Very unattractive $\quad \square \quad[\quad \square \quad \square \quad \square \quad \square \quad \square \quad \square \quad \square \quad$ Very attractive

2) Imagine that your partner takes the job:

What should the division of labour in the household between you and your partner look like?

$\underline{\text { Domestic work }}$

All you

口.

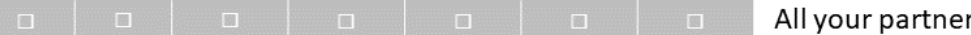

Childcare

All you

\begin{tabular}{|l|l|l|l|l|l|}
\hline$\square$ & $\square$ & $\square$ & $\square$ & $\square$ & $\square$ \\
\hline
\end{tabular}

All your partner

3) Imagine that your partner takes the job:

How much do you have to reduce your working time?

Not at al

\begin{tabular}{l|l|l|l|}
\hline$\square$ & $\square$ & $\square$ & $\square$
\end{tabular}

$\square$

Very much 


\section{Table A3: Effects of fathers' and mothers' flexible hours on fathers' current contribution and raw difference}

Dependent variable:

Model: OLS Regression with clustered standard errors

Hourly wage

$\leq$ Working hours

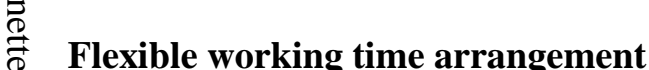

$\bigoplus$

Qualification

ref.: Approx. adequate

Under

$\stackrel{0}{\rightarrow}$

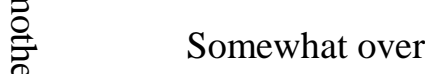

$\stackrel{s}{\infty}$

司 Very over

$\stackrel{\circ}{\stackrel{2}{2}}$

\&. Staff responsibility

$\underset{-.}{ }$ ref.: None

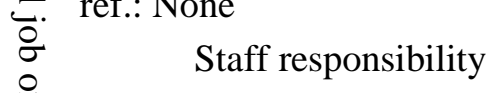

$\stackrel{0}{\stackrel{0}{Q}}$

Career prospects

ref.: None

Career prospects
Contribution before mothers' hypothetical re-employment [1 to 7]

Childcare Household work
Raw Difference (after minus before) mothers' hypothetical re-employment [-6 to 6$]$

Childcare $\quad$ Household work

(0.038)

$0.043 * * *$

(0.004)

0.062

(0.062)

(0.063)

$-0.147+\quad-0.063$

(0.081) (0.090)

$\begin{array}{ll}-0.024 & -0.069\end{array}$

$\begin{array}{ll}(0.079) & (0.087)\end{array}$

\begin{tabular}{l|l}
0.017 & -0.028
\end{tabular}

$\begin{array}{ll}(0.060) & (0.079)\end{array}$

0.082

0.115

(0.061)

(0.069)

0.031

0.069 
Dependent variable:

Model: OLS Regression with clustered standard errors

Fixed-term contract

ref.: Unlimited

Fixed-term contract: 2 years

Company childcare

ref.: None

Company $\mathrm{CCP}$, half working hours

Company $\mathrm{CCP}$, full working hours

\begin{tabular}{|c|c|}
\hline & Age in years \\
\hline & Years of education \\
\hline 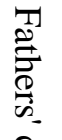 & $\begin{array}{l}\text { Labor market status } \\
\text { ref.: Blue-collar worker }\end{array}$ \\
\hline$\stackrel{\overbrace{}}{\stackrel{\partial}{ٍ ~}}$ & White-collar worker \\
\hline 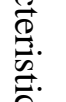 & Self-employed \\
\hline & Other \\
\hline
\end{tabular}

Male net income in 100 euros
Contribution before mothers' hypothetical re-employment [1 to 7]

Childcare $\quad$ Household work

$\mathrm{b} / \mathrm{se}$ $\mathrm{b} / \mathrm{se}$

/se

0.035
$(0.021)$

$-0.038$

(0.110)

$-0.380$

$(0.438)$

$-2.401 *$

(0.992)

$-1.605 *$

$(0.739)$

0.002

$(0.007)$
Raw Difference (after minus before) mothers' hypothetical re-employment [-6 to 6 ]

\begin{tabular}{c|c}
$\begin{array}{c}\text { Childcare } \\
\mathrm{b} / \mathrm{se}\end{array}$ & $\begin{array}{c}\text { Household work } \\
\mathrm{b} / \mathrm{se}\end{array}$ \\
\hline$(0.058)$ & $(0.064)$ \\
& \\
0.001 & 0.028 \\
$(0.063)$ & $(0.065)$ \\
& \\
& \\
$0.116 *$ & 0.079 \\
$(0.056)$ & $(0.069)$ \\
0.029 & 0.088 \\
$(0.069)$ & $(0.075)$ \\
$-0.036+$ & 0.046 \\
$(0.022)$ & $(0.037)$ \\
-0.012 & 0.193 \\
$(0.098)$ & $(0.144)$ \\
& \\
0.500 & $-2.004 * * *$ \\
$(0.423)$ & $(0.560)$ \\
$4.922 * * *$ & 0.186 \\
$(0.965)$ & $(1.368)$ \\
$2.325 * * *$ & -0.548 \\
$(0.564)$ & $(1.012)$ \\
$-0.026 * * *$ & 0.005 \\
$(0.006)$ & $(0.014)$ \\
&
\end{tabular}


Dependent variable:

Model: OLS Regression with clustered standard errors

Male working hours

Male flexible working time arrangements

ref.: No

Yes

Does not apply (e.g., self-employed)

Relationship duration

Duration of the mother's interruption of employment

ref.: under 5 years

5 to 15 years

Longer than 15 years

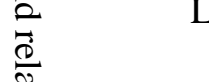

䓂.

Number of children in the household

Already employed again

ڤ్రై

Ð Age of youngest child in the household

. . ref.: Younger than 7 years

7 to under 10 years

Older than 10 years
Contribution before mothers' hypothetical re-employment [1 to 7]

Childcare Household work

$\mathrm{b} / \mathrm{se}$

$-0.036 *$

(0.017)

$-0.001$

$-0.001$

$\mathbf{- 0 . 7 7 2} * * *$

(0.168)

$1.350+$ (0.804)

$-0.034$

(0.024)

0.101

(0.268)

0.153

(0.356)

0.420

(0.298)

0.017

(0.175)

$0.844 * * *$

(0.226)

1.219

(0.437)

$-1.473$

(1.484)

$-0.033$

(0.046)

$1.177+$

(0.611)

1.018

(0.792)

$1.046+$

(0.622)

0.347

$(0.279)$

$(0.581)$

0.852
Raw Difference (after minus before) mothers' hypothetical re-employment [-6 to 6 ]

Childcare ${ }^{2}$ Household work

\begin{tabular}{l|r}
$\mathrm{b} / \mathrm{se}$ & $\mathrm{b} / \mathrm{se}$ \\
$0.059 * * *$ & 0.016
\end{tabular}

$\begin{array}{ll}0.059 * * * & 0.016\end{array}$

(0.028)

\begin{tabular}{l|l|l}
-0.242 & $0.725 * *$ & 0.426
\end{tabular}

(0.212)

(0.340)

$-2.769 * *$

$-0.933$

$(0.813)$

$0.051 *$

0.039

$(0.021)$

(0.034)

(1)

$-0.513$

$-0.912+$

$(0.270)$

$(0.459)$

$-0.564$

$-0.806$

$(0.374)$

$(0.582)$

$-0.389$

$-0.764$

(0.355)

(0.459)

$-0.036$

$-0.464 *$

(0.157)

(0.221)

$0.728 * *$

-0.953 *

(0.227)

(0.435)

$-1.417 * * *$

$-1.348 *$ 
Dependent variable:

Model: OLS Regression with clustered standard errors

Gender Roles

Women are primarily housewives and mothers

Children suffer from career orientation of fathers

Domestic help

Errands

Household work

Childcare

Care and nursing

Agreements between partners

No agreement

Increase household work

Increase own childcare

Reduce working hours
Contribution before mothers' hypothetical re-employment [1 to 7]

Childcare Household work

$\mathrm{b} / \mathrm{se}$

$(0.362)$

$-0.134$

$(0.122)$

$-0.037$

(0.110)

$1.581 * * *$

$(0.361)$

$-0.104$

$(0.254)$

$-0.445 *$

(0.220)

$-1.851 * * *$

$(0.380)$

0.403

$(0.352)$

0.065

(0.398)

0.209

(0.228)

0.327

(0.289)

Household work

Raw Difference (after minus before) mothers' hypothetical re-employment [-6 to 6 ]

\begin{tabular}{c|c}
$\begin{array}{c}\text { Childcare } \\
\mathrm{b} / \mathrm{se}\end{array}$ & $\begin{array}{c}\text { Household work } \\
\mathrm{b} / \mathrm{se}\end{array}$ \\
\hline$(0.319)$ & $(0.648)$ \\
& \\
0.073 & 0.091 \\
$(0.104)$ & $(0.150)$ \\
$0.193+$ & 0.169 \\
$(0.103)$ & $(0.175)$ \\
& \\
$-1.660 * *$ & $-1.405 *$ \\
$(0.594)$ & $(0.585)$ \\
0.389 & 0.108 \\
$(0.269)$ & $(0.455)$ \\
-0.170 & -0.167 \\
$(0.196)$ & $(0.351)$ \\
$2.534 * * *$ & 0.341 \\
$(0.453)$ & $(0.791)$ \\
& \\
-0.446 & 0.436 \\
$(0.376)$ & $(0.533)$ \\
0.292 & 0.110 \\
$(0.356)$ & $(0.546)$ \\
$-0.496+$ & 0.172 \\
$(0.257)$ & $(0.396)$ \\
$-0.544 *$ & -0.495 \\
$(0.266)$ & $(0.569)$ \\
& \\
&
\end{tabular}


Dependent variable:

Model: OLS Regression with clustered standard errors Help with caring for relatives

Other

\begin{tabular}{lc}
\multicolumn{1}{c}{ Other } & -0.385 \\
& $(0.305)$ \\
\hline Intercept & $3.563 * *$ \\
& $(1.280)$ \\
\hline Vignette-Evaluations & 64 \\
Fathers & 0.436 \\
Pseudo-R-squared &
\end{tabular}

Clustered standard errors in parentheses $(+\mathrm{p}<0.10, * \mathrm{p}<0.05, * * \mathrm{p}<0.01, * * * \mathrm{p}<0.001)$.
Raw Difference (after minus before) mothers' hypothetical re-employment hypothetical re-employment [1 to 7]

\begin{tabular}{l|l} 
Childcare & Household work
\end{tabular}

$\mathrm{b} / \mathrm{se}$

0.188

(0.396)

$\mathrm{b} / \mathrm{se}$

0.252

$(0.528)$

$-1.451 *$

$(0.715)$

$6.370 *$

(2.586)

64

0.170

Childcare $\quad$ Household work

\begin{tabular}{l|l}
$\mathrm{b} / \mathrm{se}$ & $\mathrm{b} / \mathrm{se}$
\end{tabular}

\begin{tabular}{l|l}
0.032 & 0.300
\end{tabular}

$\begin{array}{ll}(0.316) & (0.415)\end{array}$

\begin{tabular}{l|l}
0.068 & $1.073+$
\end{tabular}

\begin{tabular}{l|l}
$(0.420)$ & $(0.609)$ \\
\hline-0.541 & -2.352
\end{tabular}

\begin{tabular}{l|l}
-0.541 & -2.352
\end{tabular}

\begin{tabular}{l|l} 
(1.348) & (2.145)
\end{tabular}

\begin{tabular}{c|c}
506 & 512 \\
64 & 64 \\
0.540 & 0.454
\end{tabular}

\begin{tabular}{l|l}
0.540 & 0.454
\end{tabular}


Table A4: Effects of fathers' and mothers' flexible hours on mothers' probability of increased male contributions

Dependent variable: Does mother expect father to contribute more to ... after (hypothetical) re-employment [no/yes]

Model: Logistic Regression with clustered standard errors

Dimension: Hourly wage

Dimension: Working hours

Dimension: Flexible working time arrangement

Dimension: Qualification ref.: Approx. adequate

Under

(1)

Somewhat over

Very over

\begin{tabular}{c|c}
$\begin{array}{c}\text { Childcare } \\
\text { b/se }\end{array}$ & $\begin{array}{c}\text { Household work } \\
\text { b/se }\end{array}$ \\
\hline $0.017+$ & -0.002 \\
$(0.009)$ & $(0.010)$ \\
$0.018 * * *$ & $0.020 * * *$ \\
$(0.001)$ & $(0.001)$ \\
$\mathbf{0 . 0 2 4}$ & $\mathbf{0 . 0 0 3}$ \\
$(\mathbf{0 . 0 2 9})$ & $(\mathbf{0 . 0 3 3 )}$
\end{tabular}

0.000

0.030

$(0.039)$

0.021

$(0.044)$

0.069

$(0.041)$

$-0.009$

(0.044)

$(0.036)$

0.059

要

Dimension: Staff responsibility ref.: None

Staff responsibility

$-0.012$

$(0.041)$

Dimension: Career prospects ref.: None

0.032

$(0.030)$

Career prospects

$-0.041$

$-0.039$

$(0.026)$

(0.027)

Dimension: Fixed term contract ref.: Unlimited

Fixed-term contract: 2 years

0.024

(0.028)

(0.024)

Dimension: Company childcare ref.: None

Company CCP, half working hours

$-0.078 *$

0.015

$(0.034)$

(0.041)

$-0.012$

$0.069+$

Company CCP, full working hours

Age of the respondent

$(0.047)$

0.008

$(0.005)$

0.021

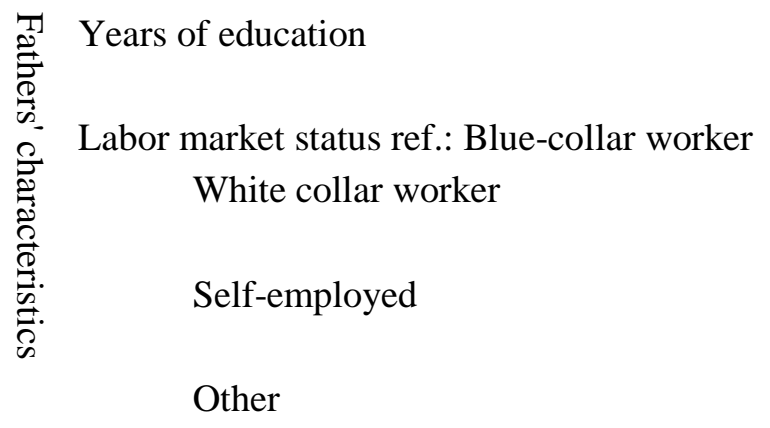

Years of education

(0.025)

$(0.038)$

0.005

$(0.005)$

$0.052 *$

(0.022)

$\begin{array}{cc} & \text { Labor market status ref.: Blue-collar worker } \\ & \text { White collar worker } \\ & \\ & \\ & \\ 0.0 & \text { Other }\end{array}$

$-0.376 * * *$

$-0.157$

$(0.075)$

(0.113)

$0.246 * * *$

$0.263 *$

$(0.061)$

(0.109)

$-0.114$

$0.244 *$

(0.191)

(0.108) 
Dependent variable: Does mother expect father to contribute more to ... after (hypothetical) re-employment [no/yes]

Model: Logistic Regression with clustered standard errors

Male net income in 100 euros

Household work

Male working hours

Childcare

\begin{tabular}{r|r}
$\mathrm{b} / \mathrm{se}$ & $\mathrm{b} / \mathrm{se}$ \\
\hline 0.005 & 0.000 \\
$(0.004)$ & $(0.003)$
\end{tabular}
Yes

$-0.021 * *$
$(0.007)$

0.002

$(0.007)$

\section{Male flexible working time arrangements ref.: No}

0.079

(0.075)

Does not apply (e.g., self-employed)

Relationship duration

$-0.394 * * *$

$(0.043)$

$-0.004$

$(0.008)$

Duration of the woman's interruption of employment ref.:

under 5 years

5 to 15 years

$(0.135)$

0.174

Longer than 15 years

$(0.153)$

Already employed again

$-0.147$

$(0.165)$

0.060

$(0.067)$

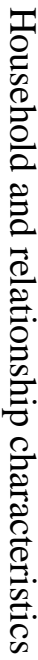

Number of children (younger than 18 years) in household

$$
(0.067)
$$

Age of youngest child (younger than 18 years) in household

ref.: Younger than 7 years

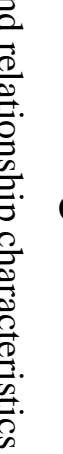

7 to under 10 years

Older than 10 years

Gender Roles

Women are primarily housewives and mothers
Children suffer from career orientation of fathers

Domestic help

Errands

Household work

$-0.197 * *$

$(0.074)$

Childcare

Care and nursing
$0.145 *$

(0.061)

$-0.315 *$

(0.160)

$-0.009$

(0.006)

(0.094)

0.359 **

(0.130)

$0.282 *$

(0.120)

$-0.024$

(0.061)

0.034

(0.085)

$-0.065$

(0.115)

$-0.075 *$

(0.033)

0.017

(0.044)

$0.319 * * *$

(0.052)

$-0.012$

(0.104)

$-0.103+$

(0.059)

$0.167+$

(0.099)

0.177
$0.320 * * *$ 
Dependent variable: Does mother expect father to contribute more to ... after (hypothetical) re-employment [no/yes]

Model: Logistic Regression with clustered standard errors

\begin{tabular}{cc|c} 
Model: Logistic Regression with clustered standard errors & $\mathrm{b} / \mathrm{se}$ & $\mathrm{b} / \mathrm{se}$ \\
\hline Increase household work & $(0.160)$ & $(0.136)$ \\
& -0.156 & $0.163+$ \\
Increase own childcare & $(0.160)$ & $(0.094)$ \\
& -0.179 & -0.040 \\
Reduce working hours & $(0.143)$ & $(0.141)$ \\
& 0.013 & -0.086 \\
Help with caring for relatives & $(0.124)$ & $(0.105)$ \\
& 0.075 & 0.016 \\
Other & $(0.117)$ & $(0.102)$ \\
& -0.205 & $0.249 * *$ \\
Vignette-Evaluations & $(0.166)$ & $(0.093)$ \\
Mothers & 495 & 495 \\
Pseudo-R-squared & 63 & 63
\end{tabular}

Average marginal effects, clustered standard errors in parentheses $(+\mathrm{p}<0.10, * \mathrm{p}<0.05, * * \mathrm{p}<0.01, * * *$ $\mathrm{p}<0.001)$. 


\section{References}

Atzmüller, C. and Steiner, P. M. (2010). Experimental Vignette Studies in Survey Research. Methodology, 6, 128-138.

Auspurg, K. and Hinz, T. (2015). Factorial Survey Experiments. Thousand Oaks, Calif.: Sage.

Auspurg, K. and Jäckle, A. (2017). First equals most important? Order effects in vignette-based measurement. Sociological Methods \& Research, 46, 490-539.

Baxter, J. (2011). Flexible Work Hours and Other Job Factors in Parental Time with Children. Social Indicators Research, 101, 239-242.

Beckmann, M. and Cornelissen, T. (2014). Self-Managed Working Time and Employee Effort: Microeconometric Evidence.

Berk, S. F. (1985). The Gender Factory: The Apportionment of Work in American Households. New York: Plenum.

Bernardi, F., Chakhaia, L. and Leopold, L. (2017). 'Sing Me a Song with Social Significance'. The (Mis)Use of Statistical Significance Testing in European Sociological Research. European Sociological Review, 33, 1-15.

Bianchi, S. M., Milkie, M. A., Sayer, L. C. and Robinson, J. P. (2000). Is Anyone Doing the Housework? Trends in the Gender Division of Household Labor*. Social Forces, 79, 191-228.

Blood, R. O. and Wolfe, D. M. (1960). Husbands and Wives. The Dynamics of Married Living. New York: Free Press.

Blossfeld, H.-P. (1997). Women's Part-Time Employment and the Family Cycle: A Cross-National Comparison. In Blossfeld, H.-P. and Hakim, C. (Eds.). Between equalization and marginalization: Women working part-time in Europe and the United States of America. Oxford and New York: Oxford University Press, pp. 315-324.

Brayfield, A. (1995). Juggling Jobs and Kids. The Impact of Employment Schedules on Fathers' Caring for Children. Journal of Marriage and the Family, 57, 321-332.

Brines, J. (1993). The Exchange Value of Housework. Rationality and Society, 5, 302-340.

Brines, J. (1994). Economic Dependency, Gender, and the Division of Labor at Home. American Journal of Sociology, 100, 652-688.

Bryan, M. L. and Sevilla, A. (2017). Flexible working in the UK and its impact on couples' time coordination. Review of Economics of the Household, 15, 1415-1437.

Coverman, S. (1985). Explaining Husbands' Participation in Domestic Labor. The Sociological Quarterly, 26, 81-97.

Craig, L. and Powell, A. (2011). Non-standard work schedules, work-family balance and the gendered division of childcare. Work, Employment and Society, 25, 274-291.

Dechant, A. and Blossfeld, H.-P. (2015). Changes in the division of labor within highly educated German couples when the first child is born. ZfF-Zeitschrift für Familienforschung/Journal of Family Research, 27, 373-396.

Dechant, A., Rost, H. and Schulz, F. (2014). Die Veränderung der Hausarbeitsteilung in Paarbeziehungen. Ein Überblick über die Längsschnittforschung und neue empirische Befunde auf Basis der pairfam-Daten. ZfF-Zeitschrift für Familienforschung/Journal of Family Research, 26, 144-168.

Diener, K., Götz, S., Schreyer, F., Stephan, G., Lenhart, J., Nisic, N. and Stöhr, J. (2015). Rückkehr ins Berufsleben nach familienbedingter Unterbrechung. IAB-Forschungsbericht, 7/2015, 1-97.

Drasch, K. (2013). Educational attainment and family-related employment interruptions in Germany: Do changing institutional settings matter? European Sociological Review, 29, 981-995.

Drasch, K. (2019). Behavioral Intentions, Actual Behavior and the Role of Personality Traits. Evidence from a Factorial Survey Among Female Labor Market Re-Entrants. methods, data, analyses, 13, 267-290.

Eurostat (2019). Reconciliation of work and family life - statistics. https://ec.europa.eu/eurostat/statisticsexplained/index.php?title=Reconciliation_of_work_and_family_life__statistics\#Career_break_for_childcare.

Evertsson, M., Grunow, D. and Aisenbrey, S. (2016). Work interruptions and young women's career prospects in Germany, Sweden and the US. Work, Employment and Society, 30, 291-308. 
Frodermann, C., Müller, D. and Abraham, M. (2013). Determinanten des Wiedereinstiegs von Müttern in den Arbeitsmarkt in Vollzeit oder Teilzeit. KZfSS Kölner Zeitschrift für Soziologie und Sozialpsychologie, 65, 645-668.

Greenhaus, J. H. and Beutell, N. J. (1985). Sources of Conflict between Work and Family Roles. The Academy of Management Review, 10, 76-88.

Grunow, D., Schulz, F. and Blossfeld, H.-P. (2012). What determines change in the division of housework over the course of marriage? International Sociology, 27, 289-307.

Hallberg, D. (2003). Synchronous leisure, jointness and household labor supply. Labour Economics, 10, 185-203.

Hewitt, B., Baxter, J. and Mieklejohn, C. (2014). Non-standard employment and fathers' time in household labour. Journal of Family Studies, 18, 175-186.

Hildebrandt, E. (2006). Balance between work and life - new corporate impositions through flexible working time or opportunity for time sovereignty? European Societies, 8, 251-272.

Hill, E. J., Hawkins, A. J., Ferris, M. and Weitzman, M. (2001). Finding an Extra Day a Week: The Positive Influence of Perceived Job Flexibility on Work and Family Life Balance. Family Relations, 50, 49-58.

Hill, E. J., Märtinson, V. K., Ferris, M. and Baker, R. Z. (2004). Beyond the Mommy Track: The Influence of New-Concept Part-Time Work for Professional Women on Work and Family. Journal of Family and Economic Issues, 25, 121-136.

Hiller, D. V. (1984). Power dependence and division of family work. Sex Roles, 10, 1003-1019.

Kelly, E. L., Ammons, S. K., Chermack, K. and Moen, P. (2010). Gendered Challenge, Gendered Response: Confronting the Ideal Worker Norm in a White-Collar Organization. Gender \& Society, 24, 281-303.

Kuhfeld, W., Tobias, R. and Garrat, M. (1994). Efficient experimental design with marketing research applications. Journal of Marketing Research, 31, 545-557.

Kühhirt, M. (2012). Childbirth and the Long-Term Division of Labour within Couples. How do Substitution, Bargaining Power, and Norms affect Parents' Time Allocation in West Germany? European Sociological Review, 28, 565-582.

Lott, Y. and Chung, H. (2016). Gender Discrepancies in the Outcomes of Schedule Control on Overtime Hours and Income in Germany. European Sociological Review, 32, 752-765.

Martens, M. F. J., Nijhuis, F. J. N., Van Boxtel, M. P. J. and Knottnerus, J. A. (1999). Flexible work schedules and mental and physical health. A study of a working population with non-traditional working hours. Journal of Organizational Behavior, 20, 35-46.

Nijp, H. H., Beckers, D. G. J., van de Voorde, K., Geurts, S. A. E. and Kompier, M. A. J. (2016). Effects of New Ways of Working on Work Hours and Work Location, Health and Job-Related Outcomes. Chronobiology International, 33, 604-618.

Nock, S. L. and Kingston, P. W. (1988). Time With Children: The Impact of Couples' Work-Time Commitments*. Social Forces, 67, 59-85.

Noonan, M. C., Estes, S. B. and Glass, J. L. (2007). Do Workplace Flexibility Policies Influence Time Spent in Domestic Labor? Journal of Family Issues, 28, 263-288.

Pierce, J. L. and Newstrom, J. W. (1980). Toward A Conceptual Clarification Of Employee Responses To Flexible Working Hours: A Work Adjustment Approach. Journal of Management, 6, 117-134.

Presser, H. B. (1994). Employment Schedules Among Dual-Earner Spouses and the Division of Household Labor by Gender. American Sociological Review, 59, 348-364.

Rapoport, B. and Le Bourdais, C. (2008). Parental Time and Working Schedules. Journal of Population Economics, 21, 903-932.

Reimer, T. (2015). Working time arrangements and family time of fathers: How work organization(s) shape fathers' opportunities to engage in childcare. Management Revue, 26, 227-252.

Rogers, W. (1994). Regression standard errors in clustered samples. Stata Technical Bulletin, 3.

Rosenfeld, R. A. and Birkelund, G. E. (1995). Women's Part-Time Work. A Cross-National Comparison. European Sociological Review, 11, 111-134.

Rosenfeld, R. A., Trappe, H. and Gornick, J. C. (2004). Gender and Work in Germany. Before and After Reunification. Annual Review of Sociology, 30, 103-124.

Rossi, P. H. and Anderson, A. B. (1982). The factorial survey approach: An introduction. In Rossi, P. and Nock, S. (Eds.). Measuring Social Judgments: The Factorial Survey Approach. Beverly Hills, CA: Sage, pp. 15-67. 
Rupp, M. (2013). Die Berufsrückkehr von Müttern unter den Bedingungen des neuen Elterngeldes: Broschüre mit zentralen Studienergebnissen. Staatsinstitut für Familienforschung an der Universität Bamberg (ifb). ifb-Materialien, 1-2013.

Sayer, L. C. (2005). Gender, Time and Inequality: Trends in Women's and Men's Paid Work, Unpaid Work and Free Time. Social Forces, 84, 285-303.

Schober, P. S. (2011). The Parenthood Effect on Gender Inequality: Explaining the Change in Paid and Domestic Work When British Couples Become Parents. European Sociological Review, 29, 74-85.

Schober, P. S. (2013). Maternal labor market return and domestic work after childbirth in Britain and Germany. Community, Work \& Family, 16, 307-326.

Schulz, F. (2010). Verbundene Lebensläufe. Wiesbaden: VS Verlag für Sozialwissenschaften.

Shockley, K. M. and Allen, T. D. (2007). When flexibility helps. Another look at the availability of flexible work arrangements and work-family conflict. Journal of Vocational Behavior, 71, 479493.

Silver, H. and Goldscheider, F. (1994). Flexible Work and Housework: Work and Family Constraints on Women's Domestic Labor*. Social Forces, 72, 1103-1119.

van der Lippe, T. (2007). Dutch workers and time pressure: Household and workplace characteristics. Work, Employment and Society, 21, 693-711.

Voßemer, J. and Heyne, S. (2019). Unemployment and Housework in Couples. Task-Specific Differences and Dynamics Over Time. Journal of Marriage and Family, 81, 1074-1090.

West, C. and Zimmerman, D. H. (1987). Doing Gender. Gender \& Society, 1, 125-151.

Wheatley, D. (2012). Work-life balance, travel-to-work, and the dual career household. Personnel Review, 41, 813-831.

Wheatley, D. (2017). Employee Satisfaction and Use of Flexible Working Arrangements. Work, Employment and Society, 31, 567-585.

Zapf, I. and Brehmer, W. (2010). Arbeitszeitkonten haben sich bewährt. Nürnberg. 